KINERJA Jurnal Ekonomi dan Bisnis

Vol. 4 No. 1 - Desember 2021

\title{
ANALISIS HARGA SAHAM PERUSAHAAN OTOMOTIF DAN KOMPONEN DI BURSA EFEK INDONESIA
}

( Periode 2011-2019)

\author{
Elly Soraya Nurulhuda \\ Anis Lutfiati \\ Topan Setiawan
}

\author{
Program Studi Manajemen Fakultas Ekonomi dan Bisnis \\ Universitas Islam As-Syafi'iyah \\ sorayaelly@gmail.com \\ anis.lutfiati@gmail.com \\ topansetiawan97@gmail.com
}

\begin{abstract}
The purpose of this study is to analyze the factors affecting stock prices, empirical study of manufacturing companies in the automotive and component sectors on the Indonesia Stock Exchange for the period 2011-2019. This research. using purposive sampling with a sample of 9 automotive and component companies. The data used in this study, in the form of secondary data. Using panel data regression with Eviews 9. The results of the research variable Earnings Per Share (EPS), Price Earning Ratio (PER), and Dividend Per Share (DPS) have a significant effect on stock prices. Earning Per Share (EPS) has no significant positive effect. Price Earning Ratio (PER) has a significant positive effect, and Dividend Per Share (DPS) has a positive and insignificant effect. The coefficient of determination ( $R$ Square) of EPS, PER, and DPS on the stock price is $84 \%$. Proving that EPS, PER and DPS explain $84 \%$ of Beta Shares, while the remaining $16 \%$ is due to other factors outside the variables studied
\end{abstract}

Keywords: Earning Per Share (EPS), Price Earning Ratio (PER), Dividend Per Share (DPS), Stock Price

\begin{abstract}
ABSTRAK
Maksud penelitian ini menganalisis factor factor mempengaruhi harga saham , Studi Empiris Perusahaan Manufacturing Sektor Otomotif dan Komponen di Bursa Efek Indonesia Periode 20112019. Penelitian ini memakai purposive sampling dengan sampel 9 perushaan otomptof dan komponen. Data dipakai di penelitian ini, berupa data sekunder. Menggunakan regresi data panel dengan Eviews 9. Hasil penelitian variabel Earnings Per Share (EPS), Price Earning Ratio (PER), dan Dividen Per Share (DPS) berpengaruh signifikan pada Harga Saham. Earning Per Share (EPS) berpengaruh positf tidak signifikan. Price Earning Ratio (PER) berpengaruh positif signifikan, dan Dividen Per Share (DPS) berpengaruh positf dtidak signifikan. Nilai koefisien determinasi ( $R$ Square) EPS, PER, dan DPS terhadap Harga Saham sebesar 84\%. Membuktikan EPS, PER dan DPS
\end{abstract}


menjelaskan sebesar $84 \%$ pada Beta Saham, sedangkan sisanya sebesar 16\% disebabkan faktor lain diluar variable yang diteliti

Kata Kunci : Earning Per Share (EPS), Price Earning Ratio (PER), Dividen Per Share (DPS), Harga Saham

\section{PENDAHULUAN}

Pasar modal mempunyai peran penting dalam memperdagangkan surat berharga jangka Panjang berupa saham dan obligasi.

Di Amerika Serikat dalam menghimpun dana peran pasar modal sangat besar, hal ini menunjukkan peran pasar modal dalam suatu negara sangat penting.merupakan (Marzuki et al., 1997). Jadi bisa dikatakan perkembangan ekonomi suatu negara bisa diukur dari perkembangan pasar modalnya, dan berapa aktif peran industri sekuritas. Makin banyak perusahaan melakukan Initial Public Offering (IPO) maka semakin banyak saham atau obligasi ditransaksikan mengindikasikan likuiditas dan besarnya ukuran pasar (market capitalization).

Analisis terhadap sector industri yang listed di BEI menjadi penting. Sektor manufaktur, khususnya sektor otomotif dan komponen menjadi sector penting. Sektor ini dalam perekonomian sangat strategis, pemerintah saat ini sedang mendorong percepatan pembangunan infrastruktur.

Bila diambil sampel 3 saham unggulan di sub sektor ini (ASII, AUTO, dan IMAS), tren harga sahamnya mengalami penurunan sejak tahun 2019 (ASII), 2015 (AUTO) dan 2016 (IMAS). Tren indeks harga saham ini berbanding terbalik dengan perkembangan industri otomotif seiring dengan kebijakan pemerintah mendorong infrastruktur jalan. Saat ini, kapitalisasi pasar di sektor manufaktur, termasuk di sub sektor otomotif dan komponen, masih relatif kecil. Indeks harga saham beberapa emiten otomotif unggulan malah mengalami tren menurun (grafik 1.5). Hal Ini bisa dikatakan anomali karena tidak bergerak seiring dengan kebijakan pemerintah dan berbagai kemudahan dari pemeritah dalam mendorong sektor ini. Pendalaman terhadap isu ini merupakan kajian menarik, mengingat ada kondisi yang berlawanan dengan teori.

\section{TINJAUAN PUSTAKA DAN HIPOTESIS}

\subsection{Harga Saham}

Harga saham mencerminkan kapasitas perusahaan yang akan menghasilkan saham, merupakan harapan penanam modal untuk memperoleh pendapatan, kas dan pengembalian, ketiga faktor ini dapat dipengaruhi makro ekonomi dan global ekonomi.

\subsection{Earning Per Share}

Earning Per Share merupakan laba bersih akan dibagikan ke pemilik saham, lalu diberikan keseluruhan lembar saham (Tandelilin, 2010). 
Sedangkan (Darmadji \& Fakhruddin, 2012) EPS menunjukkan rasio laba per saham, yaitu menggambarkan profitabilitas (pendapatan) per saham perusahaan. Makin tinggi EPS pemegang saham akan senang, dapat dikarenakan semakin banyak keuntungan dapat diberikan kepada pemilik saham dan dividen yang diperoleh oleh pemilik saham jadi meningkat. Jadi dapat Earning Per Share adalah salah satu indicator kenaikan harga saham, karena earning dari saham yang besar dilihat investor sehingga menyebabkan harga saham naik

Berdasarkan penelitian (Sorongan, 2019) berjudul EPS berpengaruh positif pada harga saham. Dari teori serta penelitian sebelumnya, hipotesis penelitian ini EPS berpengaruh positif pada Harga Saham

\subsection{Price Earning Ratio}

Price Earning Ratio yaitu rasio yang dipakai investor untuk mengukur dan menganalisa apakah saham tersebut menghasilkan atau rugi. Bila saham suatu perusahaan memiliki rasio PER besar, maka semakin besar pada keuntungan bersih dari setiap lembar sahamnya. Menurut (Nurlitasari, 2015) PER yaitu rasio menentukan pendaptan perusahaan atau emiten terhadap harga sahamnya.

Menurut (Husnan, 2009), semakin besar PER, harga saham akan makin tinggi dibandingkan dengan laba per saham. Sebab itu, PER tinggi menunjukkan harga saham lebih tinggi dengan laba per saham. Perusahaan dengan PER tinggi menyebabkan penanam modal tertarik mendapatkan saham sehingga menaikkan investasinya.

Sesuai dengan penelitian sebelumnya (Oktaviani \& Agustin, 2017) menunjukkan bahwa price-earnings ratis dapat bberpengaruh posiitif signifikan terhadap harga saham. Penelitian lain (Maria \& Budiantara, 2015) mengemukakan price-earnings ratios berpengaruh pada harga saham. Penelitian sebelumnya, hipotesisnya adalah price-earnings ratios berpengaruh pada harga saham.

\subsection{Dividen Per Share}

Dividen adalah ukuran berapa besar dividen akan investor dapatkan dibandingkan jumlah saham yang tersedia selama periode (Tandelilin, 2010). Patokan ini menunjukkan keuntungan yang diterima pemegang saham dalam bentuk dividen

(Sutrisno, 2003) berpendapat bahwa peningkatan dividen per saham akan mendorong pemodal membeli saham. Jumlah saham yang dibeli oleh investor berarti saham perusahaan akan meningkat di bursa effek.

Dari penelitian (Oktaviani \& Agustin, 2017) menjelaskan dividen per saham berpengaruh signifikan pada harga saham. Penelitian (Fitri \& Triyonowati, 2012) menyimpulkan pula dividen per saham berpengaruh terhadap harga saham. Dari penelitian sebelumnya, hipotesis nya adalah dividen per saham berpengaruh positif terhadap harga saham. 


\section{Kerangka Konseptual}

Kerangka pemikiran nya yaitu :

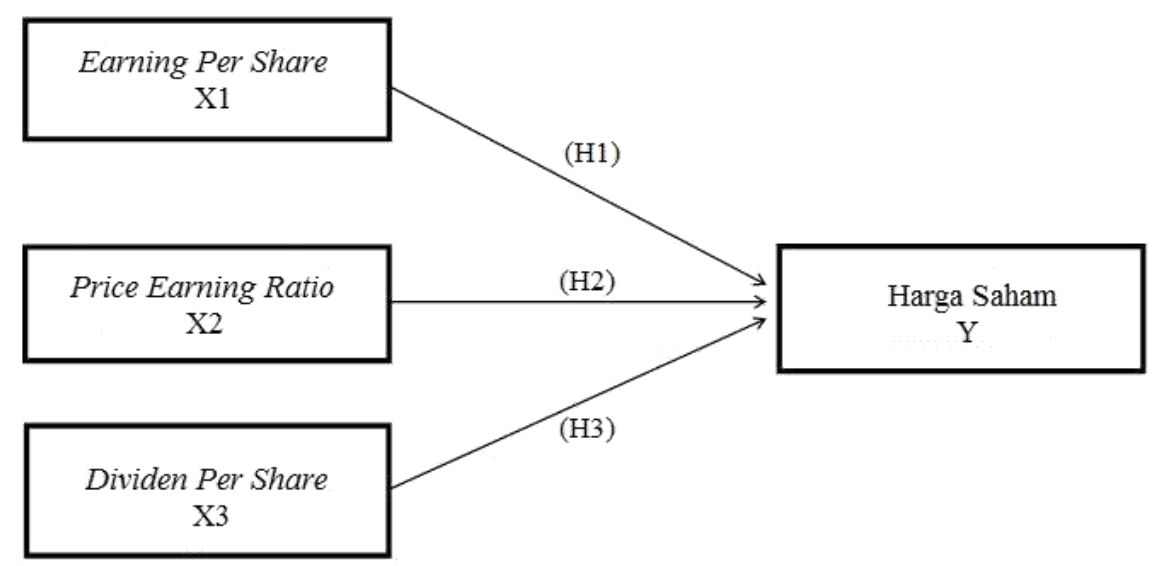

Gambar 1

Kerangka Pemikiran

\section{METODE PENELITIAN}

\subsection{Populasi, Sampel, dan Metode Penentuan Sampel}

Populasi penelitian ada 17 perusahaan otomotif dan komponen pada Bursa Efek Indonesia antara 2011-2019. Metode yang dipakai dalam menentukan sampel yaitu purposive sampling, yaitu cara pengambilan sampel tidak diacak atau berdasarkan penetapan ketentua telah dikembangkan. BEI memiliki sembilan sampel perusahaan sub-sektor otomotif dan komponen pada BEI.

\subsection{Jenis dan Sumber Data}

Survei memakai data kuantitatif dari laporan keuangan tahunan pada perusahaan yang diteliti. Situs BEI www.idx.co.id dari Laporan tahunan web dari perusahaan yang diteliti.

\subsection{Metode Pengumpulan Data}

Data memakai data panel karena jumlah sampel melebihi 50 dan selama 9 tahun atau dari periode 2011 hingga 2019.

3.4 Analisa Data Panel

Berdasarkan (A. Widarjono, 2013), persamaan regresi data panel, yaitu : 


$$
Y=a+b 1 x 1 i t+b 2 x 2 i t+b 3 x 3 i t+e
$$

\section{Keterangan :}

$\mathrm{Y}=$ Harga Saham

$\mathrm{a}=$ Konstanta

$\mathrm{b}_{1}=$ Koefisien Earning Per Share

$\mathrm{b}_{2}=$ Koefisien Price Earning Ratio

$\mathrm{b}_{3}=$ Koefisien Dividen Per Share

$\mathrm{X}_{1}=$ Earning Per Share

$\mathrm{X}_{2}=$ Price Earning Ratio

$\mathrm{X}_{3}=$ Dividen Per Share

$\mathrm{i}=$ Perusahaan

$\mathrm{t}=$ Waktu

$\mathrm{e}=$ Error

\section{HASIL DAN PEMBASAHAN}

\subsection{Analisis Deskriptif Statistik}

Pengolahan data yaitu :

Tabel 1

Statistika Deskriptif Variabel

\begin{tabular}{|c|c|c|c|c|}
\hline $\begin{array}{l}\text { Date: } 08 / 07 / 21 \\
\text { Time: } 09: 57 \\
\text { Sample: } 2011\end{array}$ & & & & \\
\hline & HARGASAHAM & EPS & PER & DPS \\
\hline Mean & 5408.198 & 398.3130 & 35.24407 & 149.0926 \\
\hline Median & 2525.000 & 181.0000 & 15.66000 & 62.00000 \\
\hline Maximum & 35400.00 & 3033.000 & 552.0000 & 1213.000 \\
\hline Minimum & 350.0000 & -338.0000 & -143.0200 & 0.000000 \\
\hline Std. Dev. & 6882.853 & 616.6967 & 89.54712 & 253.7142 \\
\hline Skewness & 2.341448 & 2.420448 & 3.731209 & 2.645745 \\
\hline Kurtosis & 8.407698 & 9.476829 & 19.73905 & 9.714230 \\
\hline Jarque-Bera & 172.7079 & 220.6696 & 1133.607 & 246.6475 \\
\hline Probability & 0.000000 & 0.000000 & 0.000000 & 0.000000 \\
\hline Sum & 438064.0 & 32263.35 & 2854.770 & 12076.50 \\
\hline Sum Sq. Dev. & $3.79 \mathrm{E}+09$ & 30425181 & 641495.0 & 5149673. \\
\hline Observations & 81 & 81 & 81 & 81 \\
\hline
\end{tabular}

Sumber: Hasil Eviews 9 Descriptive Statistic 


\subsection{Analisis Regresi Data Panel}

Pilihan menggunakan fixed effect, yaitu :

Tabel 2

\section{Hasil Pengujian}

\begin{tabular}{|c|c|c|c|c|}
\hline \multicolumn{5}{|c|}{$\begin{array}{l}\text { Dependent Variable: LOGHARGASAHAM } \\
\text { Method: Panel Least Squares } \\
\text { Date: 08/07/21 Time: } 10: 01 \\
\text { Sample: } 20112019 \\
\text { Periods included: } 9 \\
\text { Cross-sections included: } 9 \\
\text { Total panel (balanced) observations: } 81\end{array}$} \\
\hline Variable & Coefficient & Std. Error & t-Statistic & Prob. \\
\hline $\begin{array}{l}\text { C } \\
\text { EPS } \\
\text { PER } \\
\text { DPS }\end{array}$ & $\begin{array}{l}7.679347 \\
0.000278 \\
0.002627 \\
0.000716\end{array}$ & $\begin{array}{l}0.097477 \\
0.000241 \\
0.000913 \\
0.000660\end{array}$ & $\begin{array}{l}78.78124 \\
1.156539 \\
2.877707 \\
1.085295\end{array}$ & $\begin{array}{l}0.0000 \\
0.2514 \\
0.0053 \\
0.2816\end{array}$ \\
\hline \multicolumn{5}{|c|}{ Effects Specification } \\
\hline \multicolumn{5}{|c|}{ Cross-section fixed (dummy variables) } \\
\hline $\begin{array}{l}\text { R-squared } \\
\text { Adjusted R-squared } \\
\text { S.E. of regression } \\
\text { Sum squared resid } \\
\text { Log likelihood } \\
\text { F-statistic } \\
\text { Prob(F-statistic) }\end{array}$ & $\begin{array}{r}0.845759 \\
0.821170 \\
0.464476 \\
14.88589 \\
-46.32559 \\
34.39571 \\
0.000000\end{array}$ & \multicolumn{2}{|c|}{$\begin{array}{l}\text { Mean dependent var } \\
\text { S.D. dependent var } \\
\text { Akaike info criterion } \\
\text { Schwarz criterion } \\
\text { Hannan-Quinn criter. } \\
\text { Durbin-Watson stat }\end{array}$} & $\begin{array}{l}7.989536 \\
1.098356 \\
1.440138 \\
1.794871 \\
1.582462 \\
0.982636\end{array}$ \\
\hline
\end{tabular}

Berdasarkan tabel 1 tersebut, maka persamaan regresinya :

Harga Saham $=7.679347+0.000278 \mathrm{EPS}+0.002627 \mathrm{PER}+0.000716 \mathrm{DPS}+e$

\subsection{Pengujian Hipotesis}

Hasil ujii menunjukkan probabilitas EPS 0,2514, berarti nilainya lebih besar dari $\alpha$ $=0,05$. Sehingga disimpulkan EPS tidak berpengaruh signifikan terhadap harga saham.

PER 0,0053 lebih kecil dari $\alpha=0,05$, artinya PER berpengaruh signifikan terhadap harga saham. 
Variabel DPS 0,2816 lebih besar dari $\alpha=0,05$, artinya DPS tidak berpengaruh signifikan terhadap harga saham.

\section{Uji Kelayakan Model}

Dari uji nilai statistik F menjelaskan F- statistik 0,000000 lebih kecil dari $\alpha=0,05$ dikatakan EPS, PER, DPS merupakan model yang sesuai melihat pengaruh pada harga saham.

\section{Koefisien Determinasi}

Koefisien determinasi hasil estimasi Adjusted R- squared sebesar 0,845759 atau 84\%. Aertinya harga saham dapat dipengaruhi variabel independen (EPS, PER, DPS) sebesar 84\%, sebanyak $16 \%$ disebabkan faktor lain diluar penelitian

\subsection{Pembahasan}

\section{a) Pengaruh Earning Per Share terhadap Harga Saham}

Berdasarkan hasil uji variabel EPS tidak berpengaruh signifikan terhadap Harga Saham. Hasil ini tidak sesuai hipotesis. EPS berpengaruh positif terhadap Harga Saham. Memberikan sinyal harga saham tetap naik jika EPS meningkat namun kenaikkannya tidak signifikan.

Hasil ini tidak sama dengan kajian teoritis, menurut (Darmadji \& Fakhruddin, 2012) Earning Per Share mengatakan makin tinggi nilai EPS maka makin besar pula keuntungannya, menyebabkan harga saham naik. Artinya meningkatnya laba per saham perusahaan akan berpengaruh terhadap kenaikan suatu harga saham.

Penelitian juga sama dengan penelitian sebelumnya sudah dikeluarkan (Bidari. F \& Triyonowati, 2020) menunjukan EPS berpengaruh positif terhadap harga. Penanam modal dalam melakukan pembelian saham tidak mengutamakan EPS sebagai salah satu alasannya dan penenam modal tidak memperhatikan analisis fundamental untuk memutuskan membeli saham. melainkan menggunakan pengalaman, spekulasi dan faktor lain dalam mengambil keputusan berinvestasi.

\section{b) Pengaruh Price Earning Ratio terhadap Harga Saham}

Price Earning Ratio berpengaruh positif signifikan terhadap Harga Saham. Penelitian sesuai dengan hipotesis $P E R$ berpengaruh positif dan signifikan terhadap Harga Saham, artinya harga saham akan naik jika $P E R$ meningkat.

Dari penelitian sesusai dengan kajian teoritis, bahwa PER tinggi membuktikan,makin baik return saham, jadi PER menunjukkan makin baik return sahamnya. Perusahaan dengan PER tinggi menyebabkan ketertarikan penanm modal membeli saham perusahaan sehingga harga saham naik.

Temuan ini juga sama penelitian (Oktaviani \& Agustin, 2017) dan (Rahmadewi \& Abundanti, 2018) menyatakan bahwa PER berpengaruh positif dan signifikan terhadap Harga Saham 


\section{c) Pengaruh Dividen Per Share terhadap Harga Saham}

Dividen Per Share tidak berpengaruh terhadap Harga Saham, berarti penelitian tidak sesuai dengan hipotesis, DPS secara parsial berpengaruh positif dan signifikan terhadap Harga Saham. Hasil pengujian memberikan sinyal harga saham menjadi naik jika DPS meningkat.

Penelitian tidak sesuai kajian teoritis, bahwa pada umumnya para investor memiliki respon positif terhadap kenaikan dividen per lembar. Apabila jumlah dividen per saham yang dibagikan bertambah besar maka akan meningkatkan permintaan saham dan harga saham akan naik..

Penelitian sesuai dengan penelitian sebelumnya sudah dikeluarkan (Persada, 2013) menyatakan DPS berpengaruh positif tidak signifikan terhadap harga Saham.

\section{SIMPULAN DAN KETERBATASAN}

\subsection{Simpulan}

1. Earning Per Share (EPS) berpengaruh positif tidak signifikan terhadap Harga Saham pada 9 perusahaan yang terdaftar di Bursa Efek Indonesia periode $2011-2019$.

2. Price Earning Ratio (PER) berpengaruh positif signifikan terhadap Harga Saham pada 9 perusahaan yang terdaftar di Bursa Efek Indonesia periode 2011 - 2019.

3. Dividen Per Share (DPS) berpengaruh positif tidak signifikan terhadap Harga Saham pada 9 perusahaan yang terdaftar di Bursa Efek Indonesia periode $2011-2019$.

\subsection{Saran}

1. Bagi investor, perlu memperhatikan faktor seperti Price Earning Ratio sebagai tolak ukur sebelum berinvestasi di pasar modal.

2. Untuk para akademis dapat mengkaji variabel fundamental perusahaan, makro ekonomi sehingga dapat dijadikan dasar dalam menentukan faktor-faktor yang mempengaruhi Harga Saham.

3. Bagi perusahaan, memperhatikan pertumbuhan laba agar perusahaan dapat membagikan dividen secara rutin setiap tahunnya kepada pemegang saham. Dimana hal tersebut bisa menambah daya beli saham emiten di Bursa Efek. 


\section{DAFTAR PUSTAKA}

A. Widarjono. (2013). Ekonometrika: Pengantar dan Aplikasinya Disertai Panduan Eviews. UPP STIM YKPN.

Bidari. F, \& Triyonowati. (2020). Pengaruh Eps dan Dps Terhadap Harga Saham Perusahaan Pertambangan Terdaftar di BEI. 9.

Darmadji, \& Fakhruddin. (2012). Pasar Modal Di Indonesia (Edisi Keti). Salemba Empat.

Fitri, \& Triyonowati. (2012). Pengaruh Eps dan Dps Terhadap Harga Saham Perusahaan Pertambangan Terdaftar di BEI Bidari Fitri Asyari Triyonowati Sekolah Tinggi Ilmu Ekonomi Indonesia ( STIESIA ) Surabaya.

Fitriana, R., \& Condro. (2011). Mengenal Investasi Saham. Pustaka Gemilang.

Husnan, S. (2009). Dasar-dasar Teori Portofolio \& Analisis Sekuritas. UPP STIM YKPN.

Maria, \& Budiantara. (2015). Pengaruh Price Earning Ratio dan Price to Book Value Terhadap Harga Saham Perusahaan Asuransi yang Terdaftar di Bursa Efek Indoensia Tahun 2009-2012. JRAMB, Prodi Akuntansi, Fakultas Ekonomi, UMB Yogyakarta Volume 1 No. 1., Mei 2015, 1.

Marzuki, Riphat, \& Ika, S. (1997). Pengetahuan Dasar Pasar Modal. Ikatan Bankir Indonesia.

Nurlitasari, A. (2015). Pengaruh Eps, Per, Roe dan Der Terhadap Harga Saham pada Perusahaan Farmasi yang Terdaftar di Bursa Efek Indonesia Periode 2011-2014. Jurnal Manajemen Vol. 5 No. 2 Desember 2015, 2, 9.

Oktaviani, \& Agustin. (2017). Pengaruh Per, Eps, Dps, Dpr Terhadap Harga Saham pada Perusagaan Pertambangan. 6.

Persada, G. . (2013). Pengaruh Dividend Per Share, Earning Per Share dan Loan to Deposit Ratio Terhadap Harga Saham pada Perusahaan Perbankan di Bursa Efek Indonesia. 1 .

Rahmadewi, \& Abundanti. (2018). Pengaruh Eps, Per, Cr, dan Roe Terhadap Harga Saham di Bursa Efek Indonesia. Vol.7, 28.

Sorongan, F. (2019). Pengaruh Return on Assets, Return on Equity, Earning Per Share Terhadap Harga Saham pada Perusahaan Otomotif yang Terdaftar di BEI. 2.

Sutrisno. (2003). Manajemen Keuangan. Teori konsep dan aplikasi. Ekonisia.

Tandelilin, E. (2010). Portofolio dan Investasi: Teori dan Aplikasi (Edisi Pert). Kanisius. 